\title{
The politics of domestic energy vulnerability in the Barcelona region, between deconfinement and reconfinement
}

Lise Desvallées $\mathrm{a}, \mathrm{b}, *^{*}$, Olivier Coutard $\mathrm{b}_{\mathrm{b}}$, Jonathan Rutherford $\mathrm{b}_{\mathrm{b}}$

a PASSAGES, Universite de Pau et des Pays de l'Adour, E2S UPPA, Univ. Bordeaux, Univ. Bordeaux, Montaigne, ENSAP Bordeaux, CNRS, Pau, France

b LATTS, Univ Gustave Eiffel, CNRS, ENPC, F-77454 Marne-la-Vallée, France

https://doi.org/10.1016/j.geoforum.2020.08.009

Article in press, Received 30 September 2019; Received in revised form 12 August 2020; Accepted 14 August 2020

\begin{abstract}
This paper studies the diverse actions, interventions and strategies initiated to address rising energy vulnerability among low-income households in the Barcelona region over the last decade. Drawing upon recent conceptual work around the politics of energy and in-depth fieldwork conducted over more than two years, we trace the different processes and sites through which the basic socio-material conditions of domestic access to energy have become politicised. We show how this involves a two-stage movement of deconfinement and reconfinement. In a context marked by austerity, an energy inefficient urban fabric and a centralised and oligopolistic energy system, energy vulnerability emerged from the domestic and private sphere to become framed as a public problem through parliamentary debate, social protest and local authority initiatives. Yet, energy access and vulnerability have also to some extent been recontained in the space of the household through the focus of recent local policy intervention on 'low cost' measurement, audit and equipment of domestic energy use. We argue that in reprivatizing what had become a public issue and thus redistributing responsibility for change to the household level, authorities and practitioners continue to ignore the systemic factors behind energy vulnerability situations and reproduce a status quo that benefits only energy utilities. The contribution of the paper is thus to show a politics of energy access that is increasingly constituted through entangled, fluid, blurred forms of relations between domestic and collective issues. This politics allows, for example, the need for systemic change to be framed as ostensibly a concern of households and to be met through fragmented, low-cost, metrological measures at that level.
\end{abstract}

\section{Introduction}

In 2016, the Barcelona NGO initiative Fair Energy, mandated and financed by the City Council, implemented a campaign of domestic energy audits targeting the dwellings of 5,000 low-income households. One of the apartments targeted was the home of Julieta and her family for whom a local charity organization paid the rent since Julieta lost her job during the 2008 economic crisis. Julieta struggled to pay energy bills, and accepted the visit of an employee of the Fair Energy initiative in the hope that they might provide some useful advice to improve her situation. She recalled: "They came and asked a lot of questions. I mean they looked and they assessed everything - the appliances in my home, my energy consumption, my bills... They installed energy-saving light bulbs and multi-sockets, and gave me advice like turning off things and unplugging them, and changing my contract to reduce the installed

*Corresponding author at: PASSAGES, Universite de Pau et des Pays de l'Adour, E2S UPPA, Univ. Bordeaux, Univ. Bordeaux, Montaigne, ENSAP Bordeaux, CNRS, Pau, France. LATTS, Univ Gustave Eiffel, CNRS, ENPC, F-77454 Marne-la-Vallée, France. E-mail addresses: lise.desvallees@univ-pau.fr (L. Desvallées), coutard@latts.enpc.fr (O. Coutard), jonathan.rutherford@enpc.fr (J. Rutherford). URL: https://www.mendeley.com/authors/6506469366/ (O. Coutard). 
power. And to close the door to salesmen with commercial offers from the utilities... I guess I will see if it gets me lower bills..." (personal interview, May 2016). Julieta's experience was just one of many similar encounters with households hoping that home audit and advice would lead to more affordable energy for their families.

The 2008 global economic crisis unfolded in specific social, urban and policy landscapes, leading to the emergence of a 'new poverty' amongst the Spanish middle class (Serrano, 2013), and to a decline in the capacity of local public authorities to address the growing levels of urban poverty. The degradation of energy access for low-income households has come to be a key feature of this process, with notable rises in the indicators designed to measure energy deprivation, especially amongst low-income households (ACA, 2012, 2014, 2018). The concerns raised in Julieta's story above are a prime example of an apparent paradox at the heart of responses to this rising energy vulnerability. While, for a time, the increasing struggles of many Barcelona households to gain decent access to energy extended beyond the confines of the home, becoming ever more visible as a widespread public problem, recent policy initiatives have seemingly reprivatised the problem by seeking to address it primarily through a series of measures at the level of the household.

The aim of this paper is to analyse this movement and interrelation between public and private in attempts to deal with energy vulnerability - the condition of being unable to secure materially-necessary and socially-adequate levels of domestic energy services (Bouzarovski and Petrova, 2015) - and thus to highlight the diverse ways and concurrent arenas in which energy vulnerability becomes politicised. In order to achieve this, the paper develops an approach to the urban politics of energy which allows us to identify three specific areas of investigation: first, the wider political economic context in which situations of energy vulnerability emerge; second, the processes and actions through which these situations come to prominence in wide-ranging political agendas; and third, the measures through which addressing energy vulnerability is framed and enacted, thereby redrawing the lines of responsibility and control over energy access and use between the collective strategies and intervention of public authorities and the domestic sphere. While much attention is placed on visible social protest and parliamentary debate, there may be more substantive and consequential implications for household energy use from a seemingly 'soft' set of local policy interventions which subtly attempt to standardise consumption levels and shape household responsibility for their energy-related actions and behaviours, and ultimately for their access to energy.

In the next section, we draw on existing work on energy vulnerability and energy politics to set out an approach for understanding and analysing actions and strategies addressing domestic energy deprivation. The main body of the paper (sections 3 and 4) draws on indepth empirical fieldwork conducted in Cataloniat by the first author and is given over to analysis of the wider political economic context of energy vulnerability, the arenas and actions through which domestic experiences have been brought onto public and political agendas, and how public responses have sought to take the issue back to the level of the household. Section 5 draws out critical reflections on the shifting and fluid boundaries between indoor domestic space and public collective concern, on how and where

\footnotetext{
+ The research draws primarily on a series of 39 qualitative semi-structured interviews conducted between March and June 2016 with relevant stakeholders in Catalonia from all levels of administration, civil society groups, organisations in the energy sector, local journalists and researchers. These interviews were supplemented with exhaustive documentary analysis and a mapping of energy poverty/vulnerability initiatives, projects and networks using Gephi software, as well as participant observation of grassroots organisations and their meetings and associated reports and documents.
} 
politicisation processes emerge, and on the differential forms and consequences of these processes. The conclusion sums up the argument and suggests some issues for further research.

\section{Approaching the politics of energy vulnerability}

In order to trace and account for the processes and sites through which the basic sociomaterial conditions of domestic access to, and use of, energy have become politicised, we develop a conceptual framework through combining insights from long-standing work around energy poverty and vulnerability and strands of urban political ecology which draw attention to the dynamics producing and reproducing material inequalities and their wideranging consequences.

It is almost thirty years since the original notion of 'fuel poverty' emerged in the literature, conceptualizing domestic energy deprivation as the combination of the dwelling's characteristics, the energy prices and household incomes (Boardman, 1991). In this perspective, fuel poverty is triggered by contextual changes such as sharp increases in energy prices and closely related to the manner in which state bodies and utilities choose to price energy and to design assistance programs. This notion has been subsequently interrogated and extended to show that these three factors are integrated in broader socio-technical configurations. The 'energy vulnerability' approach, for example, conceptualizes the dwellings as part of a larger network of infrastructure that is shaped by macro-scale urbanization processes (Bouzarovski and Petrova, 2015). Energy prices are encased in long distance, multi-relational chains linking homes to, amongst other things, geopolitical processes around primary energy sources, national and European energy strategies, down to a variety of policy schemes and measures designed to provide households with affordable energy. Finally, individual energy consumption is not determined solely by household incomes and energy prices, but also by households' material environment and technical skills, as well as by a set of expectations, norms and values quite specific to given societies and evolving over time (Shove, 2018).

Urban materiality more generally becomes a key arena for urban politics, including through "everyday struggles over ecological (re)production and consumption" (MacLeod and Jones 2011, 2450; see also Bouzarovski 2016). This approach takes us onto the terrain of urban political ecology where a number of scholars have, over the last twenty years, proceeded to trace and analyze the uneven, conflictual, dynamic and translocal processes through which urban environments are made and remade (Swyngedouw 1996; Gandy 2004; Loftus 2012), teasing out "who gains and who loses (and in what ways), who benefits and who suffers from particular processes of socio-environmental change" (Desfor and Keil, 2004, p. 10). This perspective helps to explore the dynamics around contesting urban socio-environmental, in our case energy-related, inequalities.

UPE accounts have shown how social movements carrying critical justice claims can reconfigure policies targeting domestic spaces. Indeed, many, varied possibilities for change are to be found in organized social movements able to engage in scalar strategies and to expose and contest socio-environmental inequalities (Swyngedouw and Kaika 2014). In the case of energy poverty, this potential has been demonstrated by Hilbert and Warner's (2016) study of social struggles on weatherization in Buffalo, New York. They combined a diagnosis of the materiality of energy deprivation with a critical account of the protests in low-income neighborhoods, showing the power of community-based spatial claims to contest an unequal weatherization scheme and reinvest in the energy efficiency of the city center. Other UPE 
work has focused on the importance of everyday practices, capable of opening up spaces to explore the power of small disruptions and indirect confrontations (Lawhon et al, 2014). In these accounts, ordinary practices constitute alternatives to more direct contestations seeking to overturn embedded interests, and are capable of both attracting a wider range of participants and reclaiming power through incremental steps. This approach provides stimulating cross-seeding opportunities with the energy vulnerability approach, as shown by James Angel's account of the activism of the Catalan Alliance against Energy Poverty, which contests the unequal power relations between vulnerable consumers and energy utilities by creating new "social infrastructure" dedicated to the defence of energy poor households (Angel, 2019).

In other work, particular measures, devices or policy configurations are shown to have effective political consequences on household practices or in domestic space that it becomes crucial to analyse. Biehler (2009) for example traces over time the deployment of pesticides in US public housing to deal with insect infestations. She mobilises a notion of permeability to capture not only the capacity of pests to circulate within decaying building fabrics but also the fluid and blurred boundaries between private and collective spaces and responsibilities that the combination of the insect threat and pesticide response produced. In subsequent work, she further argued for nature-society geographers to approach indoor spaces as "active political ecological spaces", providing insights on both the social and material production of indoor environments, and on how power and governance are exerted in these spaces (Biehler, 2011). Indeed, other policy measures are increasingly deployed by authorities or companies to rationalise, standardise or keep track of consumption practices. Much attention has focused for example on the role of meters in establishing a tight contractual relationship between utility companies and users (see, for example, Baptista 2016; Anand 2020). In her account of the controversial development of prepayment water meters in post-Apartheid Johannesburg, Von Schnitzler (2008) argues that the roll-out of prepaid meters, framed as a pedagogical device designed to calculate and reduce residents' water consumption, has entailed the creation of "spaces of calculability", forcing particularly poor Soweto residents to subject their daily consumption practices to a constant "metrological scrutiny" (2008, p. 899). The underlying logic was both to depoliticize the anti-apartheid rent boycotts that had unfolded during the 1980s and to produce "calculative citizens", enforcing the transition from generalized non-payment practices and an unmetered and de facto free water, to a new economy of water consumption based on full-cost recovery by water utilities. Taken as a whole, these studies of the shifting relationships between collective agendas and domestic space materialized in meters, pesticides and other devices help to understand the 'plural' political effects (Anand 2020) of implementation rationales, processes and outcomes. This draws attention to critical questions such as who is (put) in charge of the problem, how private concerns permeate into collective action (and vice versa), and who gains and who loses from particular reconfigurations.

In the following sections we mobilise this framework to study the diverse and shifting political responses to rising levels of energy vulnerability among low-income households in the Barcelona region.

\section{Understanding the context of energy vulnerability: growth and austerity in the social and urban fabric of Spain}

Taking inspiration from the work on the politics of energy in the previous section, energy vulnerability can be located at the nexus of dynamics affecting household economies and 
choices/routines, the built environment (buildings and infrastructures) and energy prices. Indeed, the successive periods of intensive growth followed by austerity that have occurred in Spain in each of these domains have created the context for the rapid increase of energy vulnerability situations.

In the decade 1997-2007, Spanish urban growth corresponded to the country's real-estate boom, fostered by a national policy encouraging the building sector and homeownership through mortgages. This period represented an unprecedented urban expansion in Spain, mainly around large metropolitan agglomerations such as Madrid and Barcelona (Burriel, 2008), with few incentives for retrofitting existing dwellings.

During this period of growth, the main national regulations on energy efficiency were provided by the first Spanish building code of 1979, whose limits for fostering an energyefficient built environment had already been exposed (Casals, 2006). The 2002 European regulation on efficiency and renovation (EPBD, 2002) could have provided renewed efficiency norms, but it was only translated in 2006 into the Spanish legislation (CTE, 2006), and enforced after the bursting of the Spanish construction bubble when the number of new constructions hit record lows (Yearwood Travezan et al., 2013). Later national strategies prioritized the renovation of existing buildings (PNAEE 2011-2020), albeit in a recession context where financial incentives were scarce. As a result, the bulk of the Spanish building stock shares low levels of energy efficiency and suffers from gradual degradation due to the lack of retrofitting. The theoretical average energy consumption of a Spanish dwelling is 200 $\mathrm{kWh} / \mathrm{m}_{2} /$ year, a value similar to French dwellings albeit in a much milder climate (Gangolells et al., 2016).

The 2008 crisis exposed the high levels of indebtedness of citizens and State institutions alike, as domestic and national economies collapsed. A crisis of the Spanish welfare state followed, when the government negotiated international assistance to recapitalize its banking system while implementing structural reforms reducing minimum social benefits and curtailing programs targeting vulnerable social groups (Jorques, 2016). These factors, together with the rise of unemployment, induced a drop in mean incomes that masked highly differentiated social impacts, with working classes more affected in the aftermath of the crisis (Buendía and Molero-Simarro, 2018). Strong social movements responded to the withdrawal of the welfare state, culminating in the 15-M, the movement of the "indignados", taking over public places in large Spanish cities to contest the political handling of the crisis and its impacts (Diaz-Cortes and Sequera, 2015).

Low energy efficiency standards exacerbated the impact of a rise in energy prices, both creating and reinforcing energy vulnerability situations. After a period of relative stability, electricity and gas prices doubled between 2007 and 2019, exceeding the mean European value around 2010 and remaining well above this value for most of the last decade. This evolution must be understood as the result of national strategies within the context of an economic crisis and resulting austerity imperatives.

From 2008 onwards, the Spanish government had to deal with the worsening of its tariff deficit, the imbalance between the revenues earned by utilities selling electricity at a price regulated by the Spanish State and their (claimed) operational costs. This deficit had been accumulating since 2001 and spiraled out of control during the crisis, reaching 26 billion euros in 2012 (CNMC, 2019). Its reduction became one of the government's main objectives in energy policy, and this priority was implemented through a rise in electricity taxes and electricity access tariffs for all consumers in the 2013 electricity market reform package (RD 9/2013). 
In the following years, a debate on the causes of the tariff deficit emerged. International Energy Agency experts attributed the deficit to the rapid increase of fuel prices for natural gas and coal and to the recession that invalidated the projections for electricity demand on which access tariffs were based, leaving utilities to supply electricity below cost (IEA, 2015). The president of the Spanish association of the five largest energy utilities, the UNESA, along with influential Spanish energy think tanks, incriminated the important State subsidies granted to new renewable electricity generation in the 2000s (from 1.2 billion euros in 2005 to 8.6 billion euros in 2012, mainly to wind and solar plants). This was because they had increased the total cost of the electricity system and further unbalanced its equilibrium with the regulated selling price (El País, 2012, Romero et al., 2014). This explanation was translated by the Spanish government into the 2013 electricity market reform package, cutting public incentives for the development of renewable plants. In parallel, alternative analyses stemming from heterodox economists such as the Economists Facing the Crisis pointed to the subsidies granted to large, conventional plants (Fabra Utray, 2012; Cotarelo, 2015; Mañé-Estrada, 2016). They argued that subsidies were embedded in compensation schemes, both for gas plants in order to facilitate their transition to a liberalized market in 1997, and for nuclear and hydropower plants selling energy at a price higher than its production cost thus allowing large profits. $\ddagger$ According to this latter narrative, the national energy strategy was designed to foster the interests of the five largest utility companies, often dubbed "the oligopoly"s. The sums paid to these companies were presented as "illegitimate" (Cotarelo, 2015) and as a financial burden that should be deducted from the Spanish tariff deficit, thus reducing energy prices. This contestation was endorsed by a group of Spanish NGOs under the name of the Platform for a new energy model - with a Catalan replica: the Network for energy sovereignty - lobbying to subtract from the public debt the subsidies granted to the five main electricity utilities.

Within a highly polarized debate, these opposing explanations are not necessarily mutually exclusive. Both place the responsibility at the level of the Spanish State for its handling of energy liberalization, leading to the accumulation of capital in generation units and to transfers of costs to all Spanish consumers irrespective of their incomes or situations, all the while effectively securing the interests of large national energy utilities.

In short, the driving forces of energy vulnerability in Spain can be linked to macro-economic dynamics of growth and recession, but can only be fully understood by taking into account the national strategies in the energy and the building sectors. Logics of capital accumulation were privileged both in energy production plants and urban growth. This led to high energy consumption urban landscapes and buildings and exposed their inhabitants to rising energy prices, driven by the transfer to all Spanish consumers of the costs of liberalization and 'transition' of the energy sector.

\section{Three modes of politicization of energy vulnerability in Catalonia}

In Catalonia, the consequences of the housing crisis, combined with low energy efficiency standards and rising energy prices, have created a context for pervasive energy vulnerability. The absence of a dedicated statistical inquiry makes any estimation of the number of affected households very difficult, but Catalan NGOs and public agencies suggest that the problem

¥ For Jorge Fabra Utray, and the Spanish energy regulator (CNE, 2008; Fabra Utray, 2012), the 1997 Spanish Electricity Law established a marginal electricity market, where the highest price paid for a kWh sold in the market sets the bar for all electricity producers. This scheme benefits companies operating plants powered by the least expensive sources: nuclear plants and old hydroelectric dams.

$\S$ The five largest electricity utilities are Endesa, Iberdrola, Naturgy, EDP España and Viesgo, federated in the Spanish association of electricity industries (UNESA). 
is widespread. The Catalan institute for public policy evaluation estimated the number of energy-poor Catalan households at between 350,000 and 550,000, or between $11 \%$ and $18 \%$ of the total number of households in the region** (Sabes-Figuera and Todeschini, 2016). Furthermore, a number of Catalan charities have written alarming reports based on data gathered during their work with low-income households, highlighting the heavy burden of energy bills on unemployed and single-parent families, and the related health hazards (see ABD, 2015; Cáritas, 2015; Ecoserveis, 2016). Enquiries conducted by the Barcelona Public Health Agency with participants of the Alliance against energy poverty highlighted that $50 \%$ of these low-income households could not afford to heat their homes in the cold months, well above the $10 \%$ Catalan average. The results also showed the heavy psychological burden of energy vulnerability, with recurrent cases of fatigue and depression that are worsened by regular calls from utilities to pay bill arrears (DESC, 2018).

In this tense context, while households have become entangled in a larger social and economic crisis, energy vulnerability has gradually become framed as a public or collective concern. We focus here in turn on three distinctive arenas in which domestic energy consumption and vulnerability became manifest and debated: in parliaments, in street protests and community meetings, and at local authority level.

\subsection{Legislating on energy vulnerability in the Spanish and Catalan parliaments}

In Spain, securing energy affordability has become a political issue in the last decade, as both the extension of energy social tariffs and their financing became contested issues at the Spanish Parliament.

In 2009, the first Spanish electricity social tariff was implemented to comply with European directives establishing common rules for domestic electricity markets asking member States to implement protection measures for vulnerable consumers (Directive 2009/72/CE). Spanish legislation complied with the directive by adopting a social tariff cancelling the rise of the regulated electricity price from 2009 onwards, and, as electricity prices kept rising, by applying from 2014 a $25 \%$ discount on two of the components of the regulated electricity price: installed power and consumption (not including the two other components: taxes and the rent of the electricity meter) (RD 216/2014, Mendoza, 2014). In this version and in the subsequent iterations of the social tariff, this discount was to be paid by the energy sector, first by energy producers based on their production capacity until 2013. This mode of calculation was effectively contested by the major utilities, leading to a redefinition of their contribution based on their market share from 2016 onwards, with a three-year gap where the social tariff was financed by the Spanish State. In both cases, three of the largest utilities, Endesa, Iberdrola and Gas Natural Fenosa paid for more than $90 \%$ of the social tariff (Mendoza, 2016).

Eligibility for social tariffs was based on social welfare benefits criteria (large families, pensioners, families where all active members were unemployed) and on consumption criteria (clients with contracted power under $3 \mathrm{~kW}$ were eligible for these lower electricity prices), provided that households contracted a regulated electricity offer and not a

\footnotetext{
** This gap in numbers is due to the different indicators employed to measure energy poverty. The largest estimation is achieved with a traditional "energy effort" ratio, where a household spending more than $10 \%$ of its medium income is deemed energy poor, whereas the smaller number elaborated by the institute only takes into account the households whose income, minus energy expenses, is inferior to the poverty risk threshold.
} 
commercial one (RD 6/2009). Eligible consumers had to apply for the social tariff, filing requests to their utility and providing evidence of their status.

The evolution of the number of beneficiaries is represented in Figure 2. It reached 2.9 million households in 2010, then steadily decreased to 2.4 million in 2016, with a fairly stable dominant share of households having under $3 \mathrm{~kW}$ of installed power, and with growing, but much smaller percentages of households meeting social welfare criteria, thus reaching only a fraction of their numbers in the Spanish societytt. This gap between potential and actual beneficiaries can be explained by the lengthy application process and the lack of advertising on the social tariff, resulting, for example, in $50 \%$ of the consumers ignoring its existence as late as 2017 (CNMC, 2017).

Figure 1 - Evolution of the number of household beneficiaries of the social tariff for electricity in Spain between 2010 and 2016 (based on CNMC data from 2016)

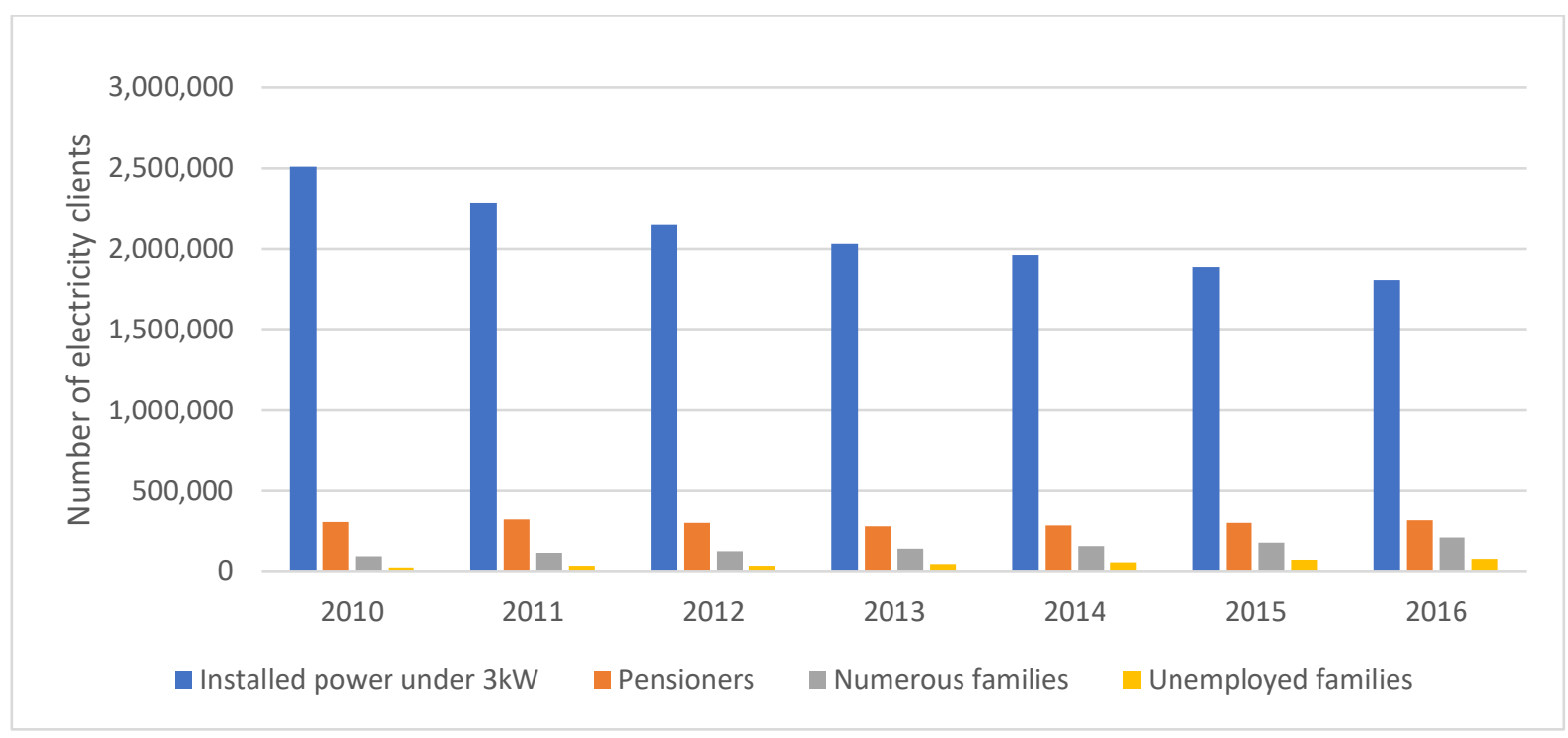

Two proposals for laws were submitted in 2013 and 2015 by the opposition coalition, the Irquierda Plural, composed of socialist and green parties but distinct from the Socialist party (PSOE). Representatives from this coalition argued in parliamentary sessions to the fact that a significant cohort of vulnerable Spanish people were not included according to the criteria chosen, and that, on the contrary, not all large households and clients who contracted low power contracts (such as secondary residences) needed to benefit from social tariffs. They used the reports produced by the Spanish NGO ACA (ACA, 2012, 2014), applying the indicator of the share of household expenditure on energy from national statistics, and estimating that some 3 million Spanish households could be considered as energy poor, a higher number than the total beneficiaries of the social tariff.

The Izquierda Plural representatives, backed by the PSOE, suggested to expand social tariffs based on income criteria, to prohibit energy disconnections in the winter, and to establish a minimal energy supply that should be guaranteed by the Spanish State. These propositions were rejected by the parliamentary majority held by the conservative Partido Popular, who argued that the existing social tariff was sufficient to protect households, and, in a conflation of energy vulnerability and income poverty, that the 2012 labor law reform provided jobs

\# For example, from 2007 to 2016, the percentage of households where all active members are unemployed rose from 500000 to 2,1 million before stabilizing around 1,8 million, well above pre-crisis levels (INE, 2016). Meanwhile, the number of unemployed households on social tariff rose from 20000 to 76000 , a significant $253 \%$ increase that reached only $3,5 \%$ of all potential beneficiaries under this employment criteria. 
and thus alleviated the burden of energy bills on low-income households. This rejection occurred in the political context of the early 2010s, when the then ruling Partido Popular adopted unpopular austerity measures and framed them as necessary responses to an alleged mismanagement by the previous PSOE government. Proposals to mitigate energy vulnerability backed by the PSOE, which was held by the Partido Popular as responsible for the rise in energy prices, were therefore framed as "demagogical" (Cortes generales, 2013).

It is in this context of controversies over the level and extent of energy affordability permitted by national social tariffs that, in 2015, a group of Catalan NGOs launched a popular legislative initiative demanding greater public supervision of evictions and energy disconnections, and the implementation of the right to a basic domestic access to energy in the Autonomous Community of Catalonia. The leaders were a large grassroots movement created to protect homeowners in debt, the Plataforma de los afectados por la hipoteca (hereafter $\mathrm{PAH}$ ), and a new grassroots organization, the energy poverty alliance (Alianza contra la pobreza energetica, APE).

This legislative initiative gathered 140,000 signatures, which allowed the group of NGOs to present it to the Catalan parliament. This first version of the proposed law dubbed "urgent measures to face the housing and energy poverty emergency" included - amongst a majority of articles aiming at overseeing and limiting housing evictions - the right to basic water and electricity services for vulnerable households. It also outlined a "principle of precaution" whereby no household should be disconnected from its energy supply before its case was submitted to local social services, for them to identify if the indebted household was vulnerable. Furthermore, it suggested that the Catalan administration could take steps to limit rent and energy bills to 30\% of households' disposable income. Finally, the proposed law called for the financial participation of the energy utilities, by requiring them to offer important discounts for low-income households and to cancel existing billing debts.

The Catalan Parliament enacted a law inspired by this initiative, the law 24/2015. During this process, it altered one of its radical aspects, the financial participation of utility companies. This change was required by the Spanish Constitutional Court, the country's highest judicial authority, which then validated the law. It should be noted that it was the ruling conservative party, the Partido Popular, which had submitted the 24/2015 law to the Spanish Constitutional Court, arguing that it exceeded the mandate of the Catalan Parliament. Hence, the issue of the mitigation of energy vulnerability became entangled in a larger political conflict over the status of Catalonia's independence from the Spanish State.

The policy implementation of the 24/2015 law was conflictual, as in the end the legislation did not state how the unpaid bills accumulated by vulnerable households would be dealt with. On the utilities side, the Spanish association of the five largest energy utilities, the UNESA, contested the implementation of the "principle of precaution" arguing that it limited the utilities' capacity to recover their debts and exposed them to unpredictable expenses. In response, a common movement of Catalan public administrations - the Barcelona city council, the Province, and several other municipalities - backed by the Catalan Autonomous Community government and under the name "common front against energy poverty", produced a policy draft stating that utilities should compensate for $50 \%$ of the unpaid bills. They stated that this should be achieved either by canceling part of the accumulated debts of vulnerable households, by financing a common fund dedicated to paying for these debts, or by creating new, more protective social tariffs. The utilities did not respond (El diario, 2017). Barcelona city council then included new criteria in the upcoming municipal public lighting service call for tender, a 65 million euros contract historically attributed to Endesa. The utilities applying to the call were required to agree to sign the policy draft produced by the "common front". Both Endesa and Gas Natural replied by seizing the 
Catalan public sector contracts tribunal, stating in their defense that this policy amounted to signing a "blank cheque" to Barcelona city council. The tribunal validated their claims, judging that the conditions of the public call for tender were "unclear" (Resolució 44/2017).

As a result, there was no common policy tool to apply the 24/2015 law. In this context, Catalan city councils established bilateral agreements with large utilities, negotiating the payment of electricity debts to protect vulnerable consumers in their jurisdictions from electricity cuts. This led to a piecemeal application of the 24/2015 law with low-income citizens of large Catalan cities (with more administrative personnel and larger budgets) receiving a more thorough protection than their rural and small town counterparts.

This burden on local Catalan administrations was increased by the evolution of the Spanish legislation in 2016 and the definition of a new protection measure distinct from social tariffs (RD 7/2016). According to this new law, local public administrations can provide extra protection to households defined by their income as "very vulnerable and at risk of social exclusion". In the case of unpaid bills, energy utilities have to inform their consumers that their access to the network can be maintained if their social services commit to paying for $50 \%$ of the debt. With an estimated 900000 "very vulnerable households" in Spain, and no additional budget transferred to local administrations across Spain, this new law is heavily criticized by social services administrations (AEDGSSE, 2018), and seemingly reproduces the flaws of the Catalan legislation throughout the country without even mentioning anything about the earlier debate in Catalonia.

\subsection{Grassroots protests in the streets and activist meetings}

A second political dynamic brought the domestic experience of energy vulnerability out onto the streets and other public spaces. Throughout the above parliamentary debates, the APE activists initiated protests in Barcelona's streets equipping themselves with blankets and candles to represent the effects of electricity disconnections. The most elaborate demonstrations were held in the local commercial offices of utility companies such as Endesa, with slogans framing large energy suppliers as rentiers enabled by the ruling Partido Popular opposed to the 24/2015 law. These demonstrations were used to advocate in favor of a member of the APE, to renegotiate their debt or to reconnect their dwelling to the network after being disconnected, and to highlight the unfair commercial practices of the utilities.

In these protests, the APE explicitly aimed to replicate the discursive strategy developed by the PAH in their advocacy against housing evictions following the bursting of the housing bubble. As an APE spokesperson made clear: "When the PAH started, people did not have this hatred towards the banks that scammed people and administrations. The PAH accomplished that. We have tried to do the same with utility companies, and we are succeeding" (interview with APE spokesperson, 10 February 2016). Indeed, the highly visible activism of the APE created media interest from Catalan and Spanish newspapers as well as televised news reports broadcast across Spain and beyond (Evole, 2014; Arte, 2018).

These direct confrontations mobilized a group of activists comprising vulnerable households and Catalan members of the Spanish association "engineers without borders" - specialized in supporting Latin development NGOs - who structured their collective action by

\# The vulnerability is established on the basis of the income indicator granting access to a number of social subsidies, the IPREM, set at $532 €$ per person and per month. Households earning less than 1.5 times the IPREM are considered as "very vulnerable and at risk of social exclusion". This status can also be attributed to other households, such as households on minimum income. 
organizing fortnightly meetings beginning in 2014. These meetings aimed both at strengthening the links between the members of the APE, and at attracting new energy poor households whose testimony about their commercial relationships with utilities would feed into a larger narrative on the struggle 'between citizenry and the electricity system' (interview with the APE spokesperson, March 2016). Between 2014 and 2018, forty meetings were held in Barcelona, during which 285 people voiced their problems to an audience and were recorded by the association in a diary. Most of the audience was composed of households experiencing or having experienced energy vulnerability, giving advice based on their own experience - and regularly voicing the complaint that the majority of the visitors did not return to the meetings after the resolution of their problem. The APE's initiative was reproduced in smaller groups in other Catalan cities including Blanes, Mollet and Barberà.

In these meetings, newcomers were provided with information regarding the energy system and, as the policy implementation of the 24/2015 law faced increasing obstacles, with advice on how to obtain protection against energy disconnections by contacting their local social services. The advice also entailed measures designed to reduce energy bills, such as lowering the contracted power and replacing contracts in the liberalized market with the regulated energy tariffss. Hyerim Yoon and David Saurí (2019) have stressed the potential of such meetings to co-produce knowledge between engineers and vulnerable households, not only on socio-technical arrangements such as energy meters and electric installations, but also on the governance of the energy system and on the strategies of public protests.

James Angel (2019) analyses these meetings as an emergent new "social infrastructure", whereby collective support - mostly composed of women - is empowering households struggling with unpaid bills and energy disconnections. He includes these organized and mutually supportive meetings alongside the establishment of illegal connections to the electricity network as practices of a 'makeshift urbanism' with transformative potential. While the extent of this practice is difficult to establish in Catalonia, social service workers and charity organizations have regularly witnessed cases of households reconnecting illegally after their access had been suspended due to payment arrears (interview with social workers in Granollers, l'Hospitalet de Llobregat, Vilanova i la Geltrú in March 2016, and with NGO workers from Cáritas and Habitat3 in April 2016).

The APE strategy constitutes an 'incremental' intervention, as it targets the cumulated everyday consumption practices of many households and fills them with political meaning. In doing this, it helps households to "find their way" (introduction meeting of the APE, March 2016) in the complex world of commercial energy offers through regular collective meetings and individual support in commercial procedures.

\subsection{Local authorities: placing the fight against energy vulnerability on the agenda}

A third mode of politicization of energy vulnerability in Catalonia emerges specifically in the work involved in implementing energy vulnerability mitigation measures thus enabling novel, often experimental forms of intervention in this area. This is a concomitant but distinct mode from the two previous ones analyzed in this section. Local authorities and utilities have addressed energy issues either directly or by supporting third party NGOs, contributing to the increasing visibility of energy vulnerability as a social, collective, political issue.

SS The regulated tariff seems better adapted to low-income households, because it guarantees a fixed and stateestablished tariff for consumers, albeit without social discounts and limited to electricity contracts under 10kW of contracted power. 
Interventions in this mode commonly target individual households and aim to help them afford energy bills through low-cost tools and protocols.

This local, more piecemeal, approach is epitomized by the pilot project Energía la justa - "the Fair Energy". This project has reached about 5,000 households in the Barcelona metropolitan area and constitutes the blueprint of a series of similar projects led by a variety of NGOs, all of which have been interested in developing public-civil society partnerships and securing public subsidies in the process.

The Fair Energy pilot project is backed by two civil society organizations, Ecoserveis and $\mathrm{ABD}$, that secured a grant of 2.5 million euros from Barcelona city council which had a surplus budget to be spent on projects with a social dimension. The project took place during six months in 2016 with the dual aim of training a hundred unemployed middle-aged workers to become "energy agents" and performing free energy audits for low-income households.

An initial identification phase was delegated to local social services and charities, which were asked to transfer cases of households with bill arrears or having been subject to disconnection of their energy supply. A call center scheduled visits in the homes of these households, in order to conduct a "bill optimization" process. The bill optimization steps comprised: the lowering of the contracted power to a smaller service capacity (a common example was from $6 \mathrm{~kW}$ to $3,5 \mathrm{~kW}$ ); the switching from commercial contracts in the liberalized market to the regulated energy offer also advised by the APE; and a visit to the local social services to establish the status of a household as economically vulnerable and thus gain the legal protection against energy disconnections offered by the Catalan law 24/2015. The bill optimization procedure also entailed the immediate application for the social tariff for households in the regulated market - a criteria conditioning the eligibility to social tariffs - or a second appointment with households in the liberalized market, to give them the time to switch to the regulated market. To speed up these contract changes and to avoid commercial techniques used by utility companies to keep their existing clients in the liberalized market, the 'energy agents' carried a list of administrative forms to be signed by the households, giving the NGO the ability to finalize the procedure on their behalf. The clear goal here was to skirt intimidation strategies deployed by utility companies seeking to deter households from making changes to their contracts.*** A second visit was then dedicated to diagnosing possible energy improvements in the home. Agents carried "energy kits" including low-consumption lightbulbs, digital thermometers, insulating rubber for windowsills and dehumidifiers. These devices were meant to be inexpensive and easy to install, and did not involve any major home renovation work. Throughout these visits, everyday practices were the target of a series of recommendations, the most frequent being to turn off the light when leaving a room and to unplug electric devices - heaters, TV sets, radios, etc. - when not in use. The way these devices were operated was also addressed, with advice to use lower temperature washes, dry sheets outside in the sun, or keep bottles of water in refrigerators in order to use less energy for cooling.

These types of individual domestic interventions came to be called 'energy audits', and they have been developed throughout Catalonia by public administrations, always relying on NGOs' workers and competencies. The most active municipality has been the Barcelona city

*** The Fair Energy Project allowed the gathering of data on the energy contracts of vulnerable households. Among the grievances of the households and the project's staff alike was the "aggressive practices" used by utility salespeople in door-to-door contracting campaigns (Tirado, 2018, p.63). Energy contracts were changed without clients' knowledge, increasing the installed power and adding unsolicited commercial offers, while promising lower bills. The number of complaints in the country led the Spanish government to prohibit doorto-door sales campaigns in 2018 (RD 15/2018). 
council, with its "attention points for energy poverty" in low-income urban districts, created in 2016 as an institutionalization of the Fair Energy pilot Project - and later renamed "energy audit points" to erase the social stigma associated with the word "poverty". Since then, 80,951 individual households have received audits and 37,420 energy disconnections have been prevented (ABD, 2019), representing a significant proportion of the city's energy poor households. Indeed, according to the Standard Income and Living Conditions index, 110,000 households suffer from cold homes and 70,000 from bill arrears in Barcelona, two indicators that only marginally overlapt+t (Tirado, 2018). 80,951 households underwent a "bill optimization" process and were provided with advice on consumption practices. 786 of them (less than 1\%) were given "energy kits" comprising low-consumption lightbulbs, radiator reflectors, thermometers, power strips equipped with switches, and insulating strips adaptable to doors and windows.

However, the ambition of Barcelona's experimental policy appears to be unmatched in the wider Catalan context. Other public administrations have reproduced the energy audits policy, but have fallen short of reaching similar proportions of households. For example, while the Barcelona energy audits have reached $10 \%$ of the total population of the city, the energy audits campaign launched by the Province of Barcelona in 2016 had only reached 3,200 households by 2018 , or $0.2 \%$ of the total population of the Province (excluding the city itself). The policy was nevertheless highlighted by the Province as a success in the fight against energy deprivation, because these households were provided with energy consumption monitors - devices used to register consumption variations and to display them on a smartphone - translating the household's efforts in financial terms in order to increase its control over energy use. The administration of the Province issued press releases announcing that the 3,200 households had managed on average a 17\% reduction in their energy bills, corresponding to a saving of $225 €$ per year (Europapress, 2018). Similar initiatives led by city councils also reached only small numbers of households, with the Tarragona project achieving for example a mere 25 energy audits in 2016 for a city of more than 300,000 households (DiariMésDigital, 2016).

Energy audits have therefore become an institutionalized response of public administrations to energy vulnerability. The wider rationale of these energy audits, involving only low investment, can be traced to the context of austerity imposed on public budgets and management and to widespread concerns to reduce public spending. Indeed, the cost of an energy audit is around $200 €$ per household on average - including the installation of 'energy kits' and the staff cost - whereas an energy retrofit would cost several thousand euros per dwelling and could only be scaled up practically in large social housing estates that constitute a mere $2 \%$ of Catalan housing. Furthermore, these new services have been articulated with stricter local policies limiting the use of public social emergency funds to pay for bill arrears, together with an associated reduction of the corresponding budgets in 2018, both based on the assumption that the 'energy audit points' would reduce the need for emergency assistance.

H+T The detailed analysis of the results of the EU Standard Income and Living Conditions enquiry in Barcelona shows a limited overlap between two major energy vulnerability indicators: the "cold indicator" relying on testimonials regarding the level of thermal comfort, and bill arrears. This overlap only concerns 17 households on the 800 interviewed during the enquiry, highlighting the diversity of situations, such as households choosing to reduce their energy consumption at the expense of their thermal comfort (Tirado, 2018) 
In Catalonia, the increasing problem of domestic energy vulnerability has thus been reframed as a public problem in recent years. The process took place concomitantly in three arenas: within the Catalan parliament, through initiatives by grassroot movements; and through new practices by local governments and energy utilities. In the following section, based on these observations, we further discuss some aspects of the politics of domestic access to energy.

\section{Politicisation of energy vulnerability: deconfinement and reconfinement}

By moving between different arenas of debate and action in the previous section, we have explored how the problem of energy vulnerability, hitherto considered as a largely private, domestic and hence hidden issue, has gradually become a prominent social and political issue in Catalonia, with important implications for both policy and collective action among NGOs and communities. Reflecting back on elements from the conceptual framing of the paper, here we outline three main lessons that can be drawn from the study.

First, our account emphasises three main modes of politicisation: through legislative action, social and community movements and local government initiatives. While each of these three modes is distinctive, they are at the same time closely interconnected. Indeed, activist NGOs mobilized popular assemblies to lobby for the adoption of new legislation and used these assemblies to implement this legislation. This strategy was instrumental in establishing a new law granting a right to energy much more ambitious than the mere affordability pursued by Spanish national legislation and banning disconnections of energy supply to vulnerable households. In turn, this combination of social movements and changing legislation created a favorable political context for local authorities to add energy vulnerability mitigation to their policy repertoire. Our analysis thus highlights how a previously private issue was transformed into a social issue through a combination of radical approaches (asserting a general right to energy) and more pragmatic approaches (solving households' affordability issues) and through mutually reinforcing dynamics of systemic change (adopting new legislation) and incremental change (coping with the problem in the field).

Second, our research also shows that the process of politicization of energy vulnerability does not univocally tend toward increased publicity and visibility. Indeed the dominant approach consisting in energy audits tends to reframe the energy vulnerability issue as a domestic issue primarily involving individual households' responsibility. Hence, to a certain extent, it tends to 'reconfine' the problem of energy vulnerability that was 'deconfined' as a result of activist movements and parliamentary debates. As we have discussed, a low-cost approach was inevitable due to the minimal financial contribution of utilities and the limited budget of local governments. But the emphasis on individualized energy audits tends to pave the way for a 're-invisibilization' of the problem. In particular, the rationale underlying energy audits rests on a strong simplification of energy consumption practices, bypassing their

\# Subsequently, energy utility companies have sought to showcase their own commitments towards mitigating energy vulnerability. In 2017, the foundation of the gas and electricity utility Naturgy dedicated 150,000€ to the implementation of an "energy vulnerability plan" in collaboration with charities such as Cáritas. This plan was extended to all of Naturgy's clients in Spain and involved a call center called "attention to energy poverty", in order to implement energy audits, but also to negotiate debts by extending the deadline of the payment limits or fractioning large debts into smaller amounts. In 2018, 3,489 energy audits were conducted for its 8.5 million Spanish domestic consumers, and 406 vulnerable households were refurbished through methods presented by Naturgy as both "express" and "low cost" (Fundación Naturgy, 2019). This investment is nevertheless by far less significant than the 95 million euros of financial participation required from the company by the State to finance the social tariff - a requirement that Naturgy - along with the other five large Spanish utilities vehemently contested in 2018. These initiatives were criticized by the APE as "a disguise to keep recovering unpaid bills" (APE, 2018). 
collective dimension: the entanglement of infrastructural arrangements, energy markets regulations and social norms that structure these practices. In transforming homes into "spaces of calculability" (Von Schnitzler 2008) of energy use, audits reduce households' energy practices to their observed, quantifiable energy consumption and expenses, which can then be subjected to a narrow monitoring and recycled in aggregate statistics that can easily be used in support of optimistic policy announcements on reduced consumption, debts and disconnections and increased affordability of domestic energy. On the one hand, this approach focused on households' capacity-to-pay is consistent with social tariffs, insofar as both aim at achieving greater affordability of domestic energy for vulnerable households. But on the other hand, it departs from the energy access principle provided for by Catalan law and defended by activist movements. Indeed, a collective right to energy recedes in favor of a focus on individual efforts conditioning the help of local public administrations. By doing so, the severity of these situations is reduced to a domestic management issue and reinvisibilized.

The third contribution of the paper is to highlight the constantly fluid and blurred relations between domestic spaces and concerns, and wider collective issues. Our conclusion expands on Biehler's (2009) account of pest control in US social housing. We show that the fluidity of boundaries between private and public spaces does not only follow from the circulation of energy (or, in Biehler's study, pests). It is also the result of the politicization of a problem in which domestic spaces are involved in a dynamic where boundaries between individual and collective responsibilities, as well as between the private sphere of the domestic affairs and the public spheres of infrastructure regulation and political struggle, are being mutually redefined and rearticulated until the problem of energy vulnerability is 'reconfined' in the domestic space. In a way, this 'reconfinement' and the 're-individualization' of energy vulnerability through its reframing as a problem of household consumption and energy efficiency are coherent with the visions and serve the interests of various parties: utilities are less under pressure, local governments can claim they are fighting the problem and households (hope to) avoid the shame of having to rely on social services permanently. And audits do so at low cost — as compared, for example, with energy retrofit of buildings which also serves the interests of affected parties as they are neither willing nor able to bear the costs of more expensive schemes. But they do not solve the problem because its more structural causes remain unaddressed.

\section{Conclusion}

This paper has studied the diverse actions, interventions and strategies initiated to address the rising energy vulnerability of low-income households in the Barcelona region over the last decade. The contribution of the paper is threefold. First, we traced the different processes and sites through which the basic socio-material conditions of domestic access to energy have become politicised. This goes beyond a focus on individual or specific political sites and demonstrates that the politics of domestic energy must be viewed as relational, multifaceted and dynamic with potentially diverse outcomes. Second, we analysed the nevertheless recent focus of local policy intervention on 'low cost' measures including audits of domestic energy use and, in a few cases, the supply of some energy efficient appliances. We argued that to a large extent this relocates the issue at household level, and, through 'metrological scrutiny' in 'spaces of calculation' of energy consumption, paves the way for a re-invisibilization of the problem as the responsibility of individual households. Third, by showing how the politicization of domestic energy vulnerability could be framed as a twostage movement of deconfinement and reconfinement, we drew attention to the constantly fluid and blurred relations between domestic spaces and concerns and wider, collective public issues. We therefore highlight that although energy vulnerability is a relational issue 
that stretches (across) domestic and collective spheres, it does not necessarily follow from this relational dimension that the issue should be framed (again) as a domestic issue; rather, we argue that this 'reconfinement' is the outcome of an active political process.

These findings point to three directions for further research. First, they emphasize that more work is needed into the always shifting and porous boundaries between domestic space and individual responsibility on the one hand and collective actions and social organisation on the other. The intrinsic interdependencies of energy consumption, utility strategies and infrastructural development make the energy domain a particularly fertile terrain for investigating the relations between individual and collective. But our research could have implications in other domains where state objectives and actions are reaching into the realm of home consumption and individual choices. Second, our research confirms the importance of accounting for the tension-ladden political processes and arenas through which particular issues become problematized, made visible, and addressed through diverse, often controversial measures. Third, we highlight the importance of further investigation of the long-lasting and far-reaching social consequences of the dramatic economic measures introduced in recent years in the south of Europe and more widely. Energy vulnerability of rising numbers of households, and the inability of governments at all levels to adequately address it, is a powerful materialisation both of increasing social inequalities and of sustained policy failure to redress the balance between dominant economic interests and logics and communities left to their own (low-cost) devices. 


\section{Bibliography}

ABD, 2015. Cruixir de dents. La vivència de la pobresa energètica a l'Àrea Metropolitana de Barcelona. Associació Benestar i Desenvolupament - Fundació ABD. Available on: https://dixit.gencat.cat/ca/detalls/Article/cruixir_dents

ABD, 2019, Los Puntos de Asesoramiento Energético del Ayuntamiento de Barcelona que gestionan ABD y Ecoserveis han sido reconocidos entre las 100 mejores acciones climáticas del mundo. Blog post. Available on: https://abd.ong/desigualdad/los-puntos-deasesoramiento-energetico-del-ayuntamiento-de-barcelona-que-gestionan-abd-yecoservicios-han-sido-reconocidos-entre-las-100-mejores-acciones-climaticas-del-mundo/

ACA, 2018. Pobreza energética en España, hacia un sistema de indicadores y una estrategia de actuación estatales. Madrid. Available on : https://www.cienciasambientales.org.es

ACA, 2014. 2ndo Estudio Pobreza energética en España: analisis de tendencias. Madrid. Available on : https://www.cienciasambientales.org.es

ACA, 2012. Pobreza energética en España, Potencial de generación de empleo derivado de la rehabilitación energética de viviendas. Madrid. Available on : https://www.cienciasambientales.org.es

ADEME, 2013. Les chiffres clés du bâtiment. Agence de l'environnement et de la maîtrise de l'énergie. Available on: https://www.ademe.fr/sites/default/files/assets/documents/chiffres-cles-batimentedition-2013-8123.pdf

AEDGSSE, 2018. Bono social eléctrico: genialidad del ministerio de industria, energía y Turismo: yo invito, los servicios sociales pagan. Press note. Asociación estatal de directoras y gerentes de servicios sociales. Available on: https://www.directoressociales.com/prensa/406-bono-social-eléctrico.html

Angel, J., 2019. Irregular Connections: Everyday Energy Politics in Catalonia. International Journal of Urban and Regional Research. 43, 337-353. https://doi.org/10.1111/14682427.12729

APE, 2018, L'atenció a la vulnerabilitat de Naturgy és una cortina de fum per cobrar els deutes de les famílies que pateixen pobresa energètica. Blog post. Available on: https://pobresaenergetica.es/2019/01/22/latencio-la-vulnerabilitat-de-naturgy-es-unacortina-de-fum-per-cobrar-els-deutes-de-les-families-que-pateixen-pobresa-energetica/

Arte, 2018. Électricité, pourquoi est-elle si chère ? TV program Vox pop broadcasted by Arte on April 28th, 2018.

Biehler, D.D., Simon, G.L., 2011. The Great Indoors: Research frontiers on indoor environments as active political-ecological spaces. Progress in Human Geography. 35, 172192. https://doi.org/10.1177/0309132510376851

Biehler, D. D., 2009. Permeable homes : a historical political ecology of insects and pesticides in US public housing, Geoforum, 40, 6, 1014-1023.

Boardman, B., 1991. Fuel poverty: from cold homes to affordable warmth. Belhaven Press.

Buzar, S., 2007. The 'hidden' geographies of energy poverty in post-socialism: Between institutions and households, Geoforum, 38, 2, 224-240. doi:10.1016/j.geoforum.2006.02.007.

Bouzarovski, S., Petrova, S., 2015. A global perspective on domestic energy deprivation: Overcoming the energy poverty-fuel poverty binary. Energy Research \& Social Science. 10, 31-40. https://doi.org/10.1016/j.eirss.2015.06.007 
Bouzarovski, S., 2016. Retrofitting the City: Residential Flexibility, Resilience and the Built Environment, Sew edition. ed. I.B.Tauris, London New York.

Burriel, E., 2008. La “década prodigiosa” del urbanismo español (1997-2006). Scr. Nova 12.

Cáritas, 2015. Memória 2014 (Report). Cáritas diocesana de Barcelona, Barcelona.

Casals, X.G., 2006. Analysis of building energy regulation and certification in Europe: Their role, limitations and differences. Energy and Buildings. 38, 381-392. https://doi.org/10.1016/j.enbuild.2005.05.004

CNE, 2008. Informe complementario a la propuesta de revisión de la tarifa eléctrica a partir del 1 de julio de 2008 precios y costes de la generación de electricidad. Comisión nacional de energía. Available on: https://www.cnmc.es/expedientes/cne8208

CNMC, 2016. La cifra de beneficiarios del bono social se estabiliza, Comisión nacional de mercados. Comisión nacional de la competencia. Blog post. Available on: https://blog.cnmc.es/2016/10/18/la-cifra-de-beneficiarios-del-bono-social-se-estabiliza/

CNMC, 2017. Siete de cada diez hogares españoles desconoce sis u oferta de gas natural ode electricidadestá en el mercado regulado o libre. Blog post. Available on : http://cnmc.es/node/365511

CNMC, 2019. el Sistema eléctrico acumuló 16.602 millones de deuda a finales de 2019. Comisión nacional de la competencia. Blog post. Available on : https://blog.cnmc.es/2020/01/21/deficit-tarifa-2019-cnmc/

Cortes Generales, 2013. Diario de sesiones del congreso de los diputados pleno y diputación permanente, Sesión plenaria núm. 157 del 17 de diciembre sobre la proposición de ley de medidas para prevenir la pobreza energética, orador : Lores Lanuza, p.30. Available on :

http://www.congreso.es/portal/page/portal/Congreso/PopUpCGI?CMD=VERLST\&B ASE $=$ pu10\&FMT $=$ PUWTXDTS. fmt $\& D O C S=1-1 \& Q U E R Y=\% 28 D S C D-10-P L-$ 166.CODI. $\% 29 \#(\mathrm{P} \% \mathrm{C} 3 \%$ A1gina 30$)$

CTE, 2006. Real Decreto 314/2006, Código tecnico de la construcción Boletín oficial del estado del 28/03.

DESC, 2018, Informe II : Radiografies de la situació del dret a l'habitatge, la pobresa energètica i el seu impacte en la salut a Barcelona, Report, Observatori DESC, Agencia de Salud Publica de Barcelona, Alianza contra la pobreza energética, PAH BCN, Available on : https://observatoridesc.org/ca/ii-perspectiva-genere-sobre-dret-l-habitatge-i-pobresaenergetica-barcelona

Defensor del pueblo, 2018. El defensor del pueblo insiste en la necesidad de proteger a los consumidores, Available on: https://pradpi.es/es/noticias/espana-el-defensor-del-puebloinsiste-en-la-necesidad-de-proteger-a-los-consumidores-especialmente-los-vulnerables-antelas-continuas-subidas-de-la-luz

Desfor, G., Keil, R., 2004. Nature and the City: Making Environmental Policy in Toronto and Los Angeles, 3 edition. ed. University of Arizona Press, Tucson.

DiariMésDigital, 2016, El Ayuntamiento ha evaluado 25 hogares tarraconenses en situación de vulnerabilidad energética. Press article. Available on: https://www.diarimes.com/es/noticias/tarragona/2016/11/04/el_ayuntamiento_evaluad o_hogares_tarraconenses_situacion_vulnerabilidad_energetica_10535_1091.html

Directive 2009/72/CE, 2009. Directive of the European parlament and of the council on common rules for the internal market in electricity Official journal 08/14, 55-93. 
Ecoserveis, 2016. La pobresa energètica a la demarcació de Barcelona, propostes d'actuació des de l'ámbit local, Eines, sèrie Benestar i Ciutadania. Diputació de Barcelona. Available on: https://dixit.gencat.cat/ca/detalls/Article/pobresa_energetica_demarcacio_barcelona

El diario, 2017, Frente común catalán para que las eléctricas paguen 50\% de la pobreza energética. Press article. Available on : https://www.eldiario.es/catalunya/politica/Frentecatalan-electricas-pobreza-energetica_0_603339940.html

El País, 2012, Las causas del déficit de tarifa eléctrica, El presidente de Unesa responde al exsecretatio de Estado de Energía. Press article. Available on : https://elpais.com/economia/2012/07/06/actualidad/1341588285_197519.html

EPBD, 2002. Directive 2002/91/EC of the European Parliament and of the Council of 16 December 2002 on the energy performance of buildings Official journal 01/04, 65-71.

Europapress, 2018, Auditorías energéticas de la Diputación de Barcelona han ahorrado 225 anuales por familia. Press article. Available on: https://www.europapress.es/catalunya/noticia-auditorias-energeticas-diputacionbarcelona-ahorrado-225-anuales-familia-20180419183746.html

Evole, J., 2014. Pobreza energética. TV program Salvados broadcasted by La Sexta on December 12th, 2014.

Fabra Utray, J., 2012. El déficit tarifario en el sector eléctrico español. Papeles de economía española, Fundación la Casa de ahorros. 134. Available on: https://www.funcas.es/Publicaciones/Sumario.aspx?IdRef=1-01134

Fundación Naturgy, 2019. Re-habilitación exprés para hogares vulnerables. Soluciones de bajo coste. Report. Available on: https://www.fundacionnaturgy.org/publicacion/rehabilitacion-expres-hogares-vulnerables-soluciones-coste/

Gangolells, M., Casals, M., Forcada, N., Macarulla, M., Cuerva, E., 2016. Energy mapping of existing building stock in Spain. Journal of Cleaner Production. 112, 3895-3904. https://doi.org/10.1016/i.jclepro.2015.05.105

Harrison, C., Popke, J., 2011. "Because You Got to Have Heat": The Networked Assemblage of Energy Poverty in Eastern North Carolina. Annals of the Association of American Geographers. 101, 949-961. https://doi.org/10.1080/00045608.2011.569659

Hilbert, A., Werner, M., 2016. Turn up the heat! Contesting energy poverty in Buffalo, NY. Geoforum 74, 222-232. https://doi.org/10.1016/j.geoforum.2016.06.009

IEA, 2015. Energy Policies of IEA Countries: Spain.

INE, 2016, Encuesta de poplación activa, Report. Instituto Nacional de Estadística.

Jorques, D., 2016. Las emergencias sociales: fundamentos e intervención, Espagne, Asociación cultural y cientifica iberoamericana.

Lawhon, M., Ernstson, H., Silver, J., 2014. Provincializing Urban Political Ecology: Towards a Situated UPE Through African Urbanism. Antipode 46, 497-516. https://doi.org/10.1111/anti.12051

Lei 24/2015, 2015. de mesures urgents per a afrontar l'emergència en l'àmbit de l'habitatge i la pobresa energètica Boletin oficial del estado del 09/09, 79287-79296.

Mañé-Estrada, A., 2016. ¿Qué se esconde detrás de la factura de la luz? Informes de Economia n¹1: la desposesión de la vida cotidiana (Report). Seminari d'economia critica TAIFA, Madrid. 
Mendoza, I. 2014, La nueva regulación del sector eléctrico: nuevos derechos para los consumidores y nuevo régimen de precios, Centro de Estudios de Consumo, Availabe on : https://previa.uclm.es/centro/cesco/pdf/trabajos/33/sectorElectrico.pdf

Mendoza, I. 2016, Las comercializadoras de energía eléctrica estarán obligadas a financiar el bono social y a cofinanciar las medidas de lucha contra la pobreza energética (Report). Gómez-Acebo \& Pombo. Available on: https://www.ga-p.com/wpcontent/uploads/2018/03/las-comercializadoras-de-energia-electrica-estaran-obligadas-afinanciar-el-bono-social-y-a-cofinanciar-las-medidas-de-lucha-contra-la-pobreza-energetica2.pdf

RD 6/2009, 2009. Por el que se adoptan determinadas medidas en el sector energético y se aprueba el bono social. Boletín oficial del estado del 7/05, 111, 39404-39419.

RD 20/2012, 2012. Ley de medidas para garantizar la estabilidad presupuestaria y de fomento de la competitividad Boletín oficial del estado del 14/07, 50428-50517.

RD 7/2016, 2016. Por el que se regula el mecanismo de financiación del coste del bono social y otras medidas de protección al consumidor vulnerable de energía eléctrica. Boletín oficial del estado del 23/12, 310, 90354-90368.

RD 15/2018. De medidas urgentes para la transición energética y la protección de los consumidores. Boletín oficial del estado del 6 de Octubre 2018, 242, 97430 a 97467

Resolució 44/2017, 2017. Resolució al recurs interposat pel senyor S.M.S. en nom i representació de la societat ENDESA ENERGIA, Report. Tribunal catalá de contractes del sector públic.

Romero, J.C., Linares, P., López Otero, J., Labandeira, X., Pérez Alonso, A., 2014. Pobreza Energética en España. Análisis económico y propuestas de actuación (Report). Economics for energy, Madrid. Available on: https://eforenergy.org > Resumen_ejecutivo_2014

Sabes-Figuera, R., TodeschiniI, F., 2016. Estimació de la pobresa energètica a Catalunya (Rapport). IVALUA (Institut Catalá d'avaluació de polítiques públiques), Barcelona. Available on : https://eforenergy.org > Resumen_ejecutivo_2014

Serrano, A., 2013. Presentación. Heterogeneización y "nuevas" formas de pobreza. Cuadernos de relaciones laborales. Monográfico : nueva pobreza, 31, 2. Available on: https://revistas.ucm.es/index.php/CRLA/issue/view/2453

Swyngedouw, E., Kaika, M., 2014. Urban political ecology: great promises, deadlock... and new beginnings? Doc. Analísi Geográfica 60, 459-481. https://doi.org/doi.org/10.5565/rev/dag.155

Tirado, S., 2018., Indicadors municipals de pobresa energètica a la ciudat de Barcelona, RMIT Europe, Ajuntament de Barcelona. Available on : https://ajuntament.barcelona.cat/premsa/wp-content/uploads/2018/02/Indicadorsmunicipals-de-pobresa-energ $\% \mathrm{C} 3 \%$ A 8 tica-a-la-ciutat-de-Barcelona-Sergio-Tirado-HerreroRMIT-Europe-.pdf

von Schnitzler, A., 2008. Citizenship prepaid: water, calculability, and techno-Politics in South Africa, Joumal of Southern African Studies, 34, 4.

Yearwood Travezan, J., Harmsen, R., van Toledo, G., 2013. Policy analysis for energy efficiency in the built environment in Spain. Energy Policy 61, 317-326. https://doi.org/10.1016/j.enpol.2013.05.096

Yoon, H., Saurí, D., 2019. 'No more thirst, cold, or darkness!' - Social movements, households, and the coproduction of knowledge on water and energy vulnerability in 
Barcelona, Spain, Energy Research \& Social Science, 58, 101276. doi: 10.1016/j.erss.2019.101276. 